\title{
Assessment of water quality of some aquaculture ponds in Ho Chi Minh City
}

\author{
Đánh giá chất lượng nước của một vài ao hồ nuôi trồng thủy sản ở khu vực thành phố Hồ Chí \\ Minh
}

DUONG Thi Giang Huong*; NGUYEN Thuan Minh; TRAN Ngoc Han

Department of Environmental Science, Sai Gon University, 273 An Duong Vuong Street, District 5, Ho Chi Minh City 70000, Vietnam

\begin{abstract}
Eutrophication in aquaculture ponds is one of the major issues related to both the environment and the health of consumers. This study has selected and conducted a water-quality survey of nine freshwater aquaculture ponds in $\mathrm{Ho}$ Chi Minh City. The empirical results showed that these ponds were seriously polluted with COD and BOD 5 whose values did not meet the B2 column of the Vietnamese National Technical Regulation on Surface Water Quality (QCVN 08MT:2015/BTNMT). On the other hand, most $\mathrm{N}_{-} \mathrm{NH}_{4}{ }^{+}$and $\mathrm{N}-\mathrm{NO}_{2}{ }^{-}$concentrations in the ponds met the threshold value of B2 column. The values of the chlorophyll-a are greater than $10 \mu \mathrm{g} / \mathrm{L}$, indicating that investigated ponds are in a state of eutrophication. In addition, the results of the TSI calculations showed that most of the sites that are in hypereutrophication state and phosphorus is identified as the eutrophication limit factor in these sites.
\end{abstract}

Phú dưỡng hóa nguồn nước nuôi trồng thủy sản là một trong các vấn đề lớn liên quan đến cả môi trường và sức khỏe người tiêu dùng. Nghiên cứu này đã lựa chọn và tiến hành khảo sát chất lượng nước của chín ao hồ nuôi thủy sản trên địa bàn thành phố Hồ Chi Minh. Kết quả phân tích cho thấy các ao hồ trên bị ô nhiễm hữu cơ nặng với thông số $C O D$ và $B O D_{5}$ đều không đạt chuẩn B2 theo quy chuẩn kỹ thuật quốc gia về chất lượng nước mặt (QCVN 08-MT:2015/BTNMT). Về mặt ô nhiễm các chất dinh dưỡng, nồng độ $\mathrm{N}_{-} \mathrm{NH}_{4}^{+}$và $\mathrm{N}_{-} \mathrm{NO}_{2}^{-}$đa số chi thỏa mãn loại B2, thậm chí vượt ngưỡng quy định của cột B2. Các giá trị của thông số chlorophyll-a đều lớn hơn 10 mg/L, chứng tỏ các ao hồ khảo sát đều đang trong tình trang phú dưỡng. Thêm vào đó, kết quả tính toán chi số TSI cho thấy hầu hết các vị trí nghiên cứu đang ở trạng thái siêu phú dướng và photpho được xác định là yếu tố giới hạn sự phú dưỡng của các vị trí khảo sát nêu trên.

Keywords: aquaculture ponds, water quality, eutrophication

\section{Introduction}

Located in the Dong Nai River Basin and the Saigon River Basin, Ho Chi Minh City's freshwater aquaculture sector has experienced rapid development in recent years to satisfy the food needs of the people with small-scale, dispersed production and diverse audience. Regarding aquaculture, despite the rapid urbanization of the city and the shrinking of aquaculture sector, the restructuring of agricultural production has flourished by specialized farming, the application of science and technology and the strengthening of fishery extension (including marine, brackish water and freshwater aquaculture). For instance, prawn farming in Can Gio and Nha Be Province has increased from 1999 to 2003 with more than 6,000 tons, with thousands of shrimp farming households. According to the Department of Agriculture and Rural Development of Ho Chi Minh City (2008), in 2007, freshwater aquaculture area reached 1,000 ha (716 ha in Binh Chanh Dis- trict, 145 ha in Cu Chi District, 131 ha in District 09. In the city area, there were 34 fish hatcheries of different kinds, supplying them to households in $\mathrm{Cu} \mathrm{Chi}$, Hoc Mon, Binh Chanh, District 9, etc. Up to July $1^{\text {st }}, 2016$, there was a total of 4,428 aquaculture households in Ho Chi Minh City.

However, such development is accompanied by the pollution of aquatic environment on different levels, especially the eutrophication phenomena caused by solid waste sources, domestic wastewater and the leaching nutrients from soil into lakes along with the diet of farmed species. Eutrophication is a type of water quality degradation that often occurs in water bodies with high concentrations of nutrients in the lake, causing outbreaks of aquatic plants (algae, water hyacinths and duckweed), increasing suspended solids, organic matter, reducing oxygen content in water, causing costly problems for the national economy. This leads freshwater aquaculture sector to face challenges in meeting demands for good quality products and 
aesthetics of the urban water bodies (color and odor) and should be studied to find solutions to overcome. Eutrophication can cause competition between species in the ecosystem, causing changes in the species composition of the ecosystem. In addition, some algal blooms contain toxic compounds. The consequence of eutrophication is that the algae blooms are bloated and very toxic. Phytoplankton have a negative effect on the quality of the water environment and adversely affect water quality. Blossoming algae diminish light and, therefore, slow down the growth and vegetation, and aquatic animals die off in water-borne algae-infested waters, as well as reducing the carnivores which need light to catch their prey. This changes the dominant species that affect the balance in the ecosystem. There have been certain studies on eutrophication in both natural and man-made reservoirs, lakes and ponds in Vietnam (Bui, 2007; Nguyen et al., 2010; Nguyen et al., 2012; Nguyen et al., 2015) as well as the water quality survey on rivers, lakes and canals in general in Ho Chi Minh City (VEA, 2013; HEPA, 2016). However, studies focusing on aquaculture ponds in $\mathrm{Ho}$ Chi Minh City still remain limited and most of them only evaluate pollution levels according to separate water quality parameters without integrated impact assessment.

Scientists around the world have proposed multiple parameters to assess the level of eutrophication of water bodies such as nutrients, chlorophyll-a and clarity (Secchi disk depth) for the Mediterranean region (Ignatiades, 2005; EEA, 2005), the Baltic sea (HELCOM, 2009), Taihu Lake, China (Rui et al., 2014). Others rely on the TSI index to define the trophic state for Liberty Lake, USA (BellMcKinnon, 2008), reservoirs from southeast Fujian, southeast China (Jun et al., 2012), the inland lakes of Michigan, USA (Fuller and Jodoin, 2016) and so on. These reports initially assess eutrophication situation through water quality parameters and TSI index, thereby making remedies for treatment and protection of the water sources.

In 1977, Carlson developed the TSI (Trophic State Index) for the purpose of assessing the level of water nutrient availability. This TSI indirectly assesses the quality of water through the amount of total phosphorus $(\mu \mathrm{g} / \mathrm{L})$, chlorophyll-a ( $\mu \mathrm{g} / \mathrm{L})$ and water clarity measured with Secchi disk (SD) (m). The TSI is calculated as follows (Jun et al., 2012):

$$
\begin{aligned}
& \mathrm{TSI}(\mathrm{TP})=4.15+14.42 \times \ln \mathrm{C}_{\mathrm{TP}} \\
& \mathrm{TSI}(\mathrm{Chl}-\mathrm{a})=30.6+9.81 \times \mathrm{InC}_{\text {Chl-a }} \\
& \mathrm{TSI}(\mathrm{SD})=60-14.41 \times \operatorname{InSD} \\
& \text { TSI }=0.163 \times \mathrm{TSI}(\mathrm{TP})+0.54 \times \mathrm{TSI}(\mathrm{Chla})+ \\
& 0.297 \times \mathrm{TSI}(\mathrm{SD})
\end{aligned}
$$

where $\ln C_{T P}, \ln C_{C h l-a}$ and $\ln S D$ are natural logarithm of total phosphorus concentration $(\mu \mathrm{g} / \mathrm{L})$, chlorophyll-a concentration $(\mu \mathrm{g} / \mathrm{L})$ and Secchi disk depth $(\mathrm{m})$, respectively. TSI value ranges from 0 to 100 and represents the nutritional status of water bodies as described in Table 1.

Table 1. TSI range corresponding to the nutritional status of water bodies

\begin{tabular}{ll} 
TSI range & Nutritional status \\
\hline $0<\mathrm{TSI} \leq 40$ & oligotrophic \\
$40<\mathrm{TSI} \leq 50$ & mesotrophic \\
$50<\mathrm{TSI} \leq 70$ & light eutrophic \\
$70<\mathrm{TSI} \leq 100$ & hyper-eutrophication
\end{tabular}

In addition, if the lake water has a TSI-P value of less than 40 then the lakes are of a poor nutrient type, usually characterized by clear water with little algae, small phosphorus concentrations and in deep, highly oxygenated waters all year round (according to West Virginia Department of Environment Protection - DEP, as cited by Hansen \& Christ, 2003). The medium nutrient lakes (TSI-P values between 40 and 50) also have abundant algae, with some areas of deep water being deprived of oxygen. For lakes that have been eutrophic, water quality problems, such as seasonal harvests and water shortages, have been reported. Some of the documents identify waterfowl water when the TSI-P value is between 50 and 70. Currently, DEP determines that the water quality of a lake is TSI-P $\geq 65$, corresponding to a total phosphorus concentration $\geq 68 \mu \mathrm{g} / \mathrm{L}$ (Hansen \& Christ, 2003).

From the above issues, this study analyzed water quality parameters of nine aquaculture ponds in Ho Chi Minh City. The parameters included $\mathrm{pH}, \mathrm{DO}, \mathrm{TS}$, turbidity, clarity (by Secchi disk depth - SD), COD, $\mathrm{BOD}_{5}, \mathrm{TN}, \mathrm{TP}, \mathrm{P}-\mathrm{PO}_{4}{ }^{3}, \mathrm{~N}$ $\mathrm{NH}_{4}{ }^{+}, \mathrm{N}-\mathrm{NO}_{2}{ }_{2}, \mathrm{~N}-\mathrm{NO}_{3}{ }^{-}$and chlorophyll-a. In addition, TSI index was also calculated according to three parameters SD, TP and Chl-a aiming at evaluating the quality of these ponds and to set the foundation for the improvement and management plan of water sources' quality in the city.

\section{Materials and methods}

\subsection{Sampling methods and analysis}

This research surveyed and analyzed 54 samples of surface water in six rounds of sampling, conducted from August 2015 to January 2016 (dry season) with 9 samples per round (one sample per pond). The investigated ponds are mainly for small-scale aquaculture and for recreational fishing. The activities are carried on throughout the sampling periods of time. The locations were located using GPS as shown in Figure 1 and Table 2 below. 


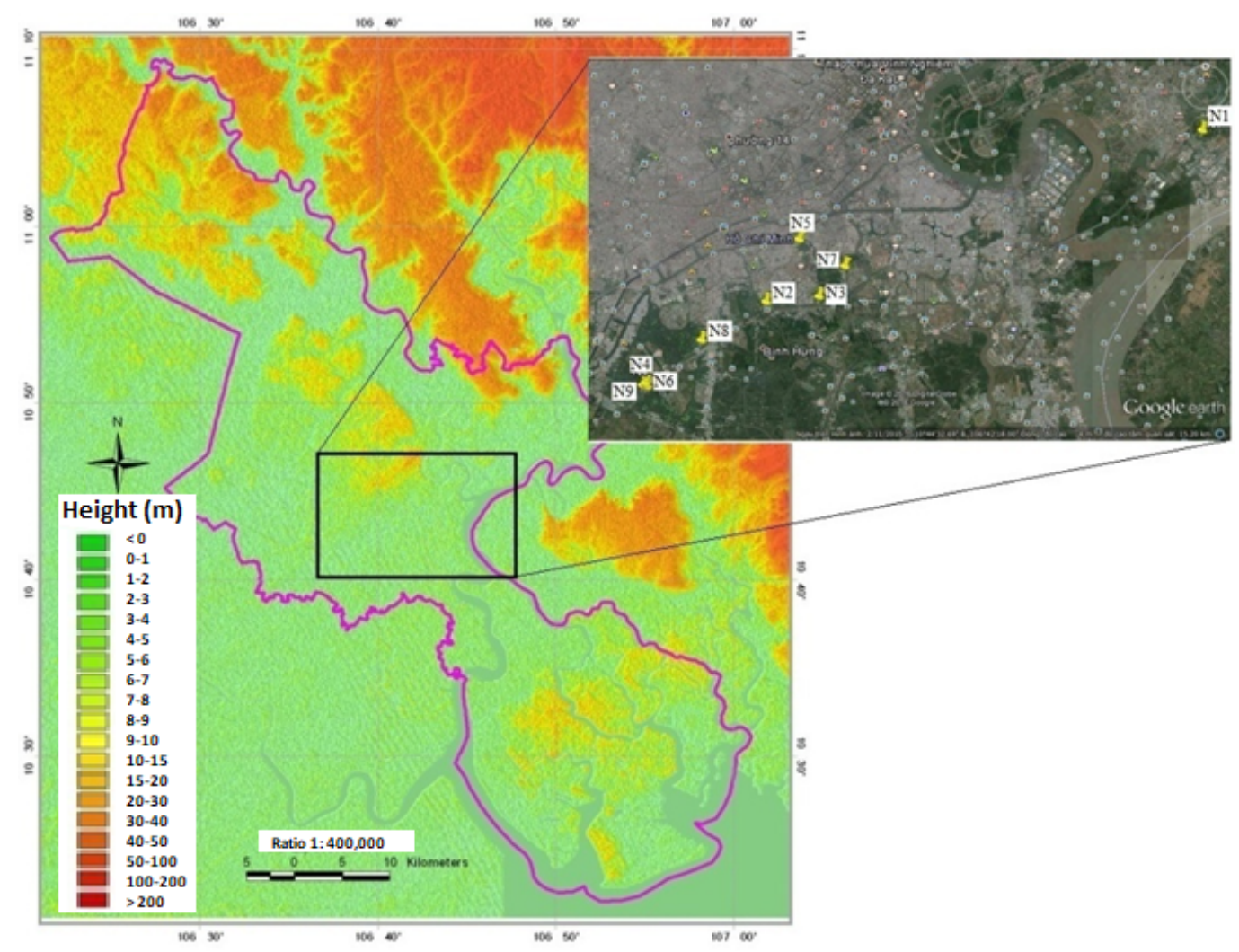

Figure 1. Sampling locations

\section{Table 2. Sampling locations' coordinates}

Sam- District

ples

N1 02

N2 Binh Chanh

N3 Binh Chanh

N4 Binh Chanh

N5 08

N6 Binh Chanh

N7 08

N8 Binh Chanh

N9 Binh Chanh

\begin{tabular}{cc}
\multicolumn{2}{c}{ Coordinates } \\
\hline Longitude & Lattide \\
$106^{\circ} 46^{\prime} 38.32 " \mathrm{E}$ & $10^{\circ} 46^{\prime} 14.31 " \mathrm{~N}$ \\
$106^{\circ} 40^{\prime} 07.20^{\prime \prime} \mathrm{E}$ & $10^{\circ} 43^{\prime} 38.30 " \mathrm{~N}$ \\
$106^{\circ} 40^{\prime} 54.83^{\prime \prime} \mathrm{E}$ & $10^{\circ} 43^{\prime} 43.08^{\prime \prime} \mathrm{N}$ \\
$106^{\circ} 38^{\prime} 16.44^{\prime \prime} \mathrm{E}$ & $10^{\circ} 42^{\prime} 22.13^{\prime \prime} \mathrm{N}$ \\
$106^{\circ} 40^{\prime} 37.00^{\prime \prime} \mathrm{E}$ & $10^{\circ} 44^{\prime} 35.10^{\prime \prime} \mathrm{N}$ \\
$106^{\circ} 38^{\prime} 20.50^{\prime \prime} \mathrm{E}$ & $10^{\circ} 42^{\prime} 21.12 " \mathrm{~N}$ \\
$106^{\circ} 41^{\prime} 17.83^{\prime \prime} \mathrm{E}$ & $10^{\circ} 44^{\prime} 10.74 " \mathrm{~N}$ \\
$106^{\circ} 39^{\prime} 09.32^{\prime \prime} \mathrm{E}$ & $10^{\circ} 43^{\prime} 03.36^{\prime \prime} \mathrm{N}$ \\
$106^{\circ} 38^{\prime} 18.69^{\prime \prime} \mathrm{E}$ & $10^{\circ} 42^{\prime} 24.13^{\prime \prime} \mathrm{N}$
\end{tabular}

Sampling procedures and preservation were followed the provisions of National Standard (TCVN) 5994:1995 Guidance on sampling from natural lakes and man-made lakes (VEA, 1995). Analysis methods were as prescribed in the National Technical Regulation (QCVN) 08-MT:2015/ BTNMT on surface water quality (VEA, 2015). Water samples were preserved at $4^{\circ} \mathrm{C}$ after adding $\mathrm{H}_{2} \mathrm{SO}_{4}$ solution for ammonia, nitrate, nitrite and COD analysis samples. Each analysis was repeated 3 times. The data was then processed with SPSS 16.0 software (SPSS, 2007).

\subsection{Water quality assessment methods}

Separate parameters were evaluated by comparison with QCVN 08-MT:2015/BTNMT due to the fact that these lakes are surface water and used as aquaculture ponds. In addition, QCVN 08-MT:2015/BTNMT (A1 column) also replaces an old version of national regulation on surface water quality for protection of aquatic lives. The classification of surface water sources for assessment and control of water quality for various purposes of water use is listed below:

A1: Good for domestic water supply after appropriate treatment, Conservation of aquatic plants and animals and other purposes as A2, B1 and B2.

A2: For the purpose of domestic water supply, but must apply appropriate treatment technology, or uses as B1 and B2.

B1: For usage in irrigation or other uses that require similar water quality or uses as B2.

B2: Waterway traffic and other purposes with low quality water requirements.

Moreover, this study also identified eutrophication limiting factors based on the ratio of total nitrogen concentration to total phosphorus concentration (TN/TP) in water bodies. When TN/TP $>16$, phosphorus is considered the limiting factor. Conversely, when TN/TP $<16, \mathrm{~N}$ is the limiting factor (Yang et al., 2008). Methods of descriptive statistics and hypothesis testing statistics were used throughout the process of data analysis.

\section{Results and discussion}

\subsection{Water quality assessment based on separate parameters}

Despite the parameters of $\mathrm{pH}, \mathrm{DO}, \mathrm{P}_{-} \mathrm{PO}_{4}{ }^{3-}$ and $\mathrm{N}-\mathrm{NO}_{3}{ }^{-}$ that meet A standard in QCVN 08-MT:2015/BTNMT (except for $\mathrm{P}_{-} \mathrm{PO}_{4}{ }^{3-}$ at $\mathrm{N} 9$ has only reached $\mathrm{B} 1, \mathrm{t}<-t_{0.05 ; 5}$ ), the majority of surveyed parameters in the lakes just meet B1 standard. However, there are some sampling 
locations only reached B2, while some even substandard B2. Total solids content of the ponds is relatively high, with values range from 45 to $222 \mathrm{mg} / \mathrm{L}$. Detailed values are listed in Table 3.

Table 3. Detailed mean measurement of water quality of investigated ponds

\begin{tabular}{|c|c|c|c|c|c|c|c|c|c|c|}
\hline & N1 & N2 & N3 & N4 & N5 & N6 & N7 & N8 & N9 & QCVN 08 (A1) \\
\hline $\mathrm{pH}$ & 6.3 & 7.0 & 7.4 & 6.7 & 6.4 & 7.7 & 7.5 & 8.2 & 8.7 & $6-8.5$ \\
\hline $\mathrm{DO}(\mathrm{mg} / \mathrm{L})$ & 6.1 & 6.3 & 7.7 & 6.7 & 5.1 & 10.0 & 7.5 & 9.4 & 10.1 & $\geq 6$ \\
\hline TS (mg/L) & 94 & 93 & 60 & 76 & 135 & 160 & 90 & 194 & 127 & - \\
\hline Turbidity (NTU) & 29 & 20 & 27 & 38 & 37 & 37 & 58 & 61 & 101 & - \\
\hline Clarity (SD - m) & 39.17 & 35.80 & 32.83 & 28.17 & 32.00 & 26.50 & 21.67 & 20.83 & 15.83 & - \\
\hline COD (mg/L) & 160.72 & 241.91 & 339.75 & 230.72 & 229.96 & 287.79 & 322.58 & 342.43 & 274.48 & 10 \\
\hline $\mathrm{BOD}_{5}(\mathrm{mg} / \mathrm{L})$ & 64.17 & 103.83 & 134.50 & 95.17 & 99.33 & 115.00 & 120.67 & 146.67 & 115.50 & 4 \\
\hline $\mathrm{TN}(\mathrm{mg} / \mathrm{L})$ & 2.73 & 3.02 & 4.02 & 4.06 & 6.47 & 3.24 & 8.27 & 6.17 & 8.35 & $0.1 *$ \\
\hline $\mathrm{N}-\mathrm{NH}_{4}^{+}(\mathrm{mg} / \mathrm{L})$ & 0.88 & 1.30 & 1.55 & 1.26 & 2.33 & 2.60 & 3.21 & 1.38 & 1.60 & 0.3 \\
\hline $\mathrm{N}-\mathrm{NO}_{2}^{-}(\mathrm{mg} / \mathrm{L})$ & 0.08 & 0.07 & 0.09 & 0.06 & 0.05 & 0.06 & 0.07 & 0.06 & 0.09 & 0.05 \\
\hline $\mathrm{N}-\mathrm{NO}_{3}{ }^{-}(\mathrm{mg} / \mathrm{L})$ & 2.6 & 1.7 & 2.5 & 2.6 & 1.7 & 1.6 & 2.0 & 3.1 & 2.1 & 2 \\
\hline $\mathrm{TP}(\mathrm{mg} / \mathrm{L})$ & 0.08 & 0.11 & 0.20 & 0.21 & 0.19 & 0.22 & 0.33 & 0.39 & 0.54 & $0.15^{*}$ \\
\hline $\mathrm{P}-\mathrm{PO}_{4}{ }^{3-}(\mathrm{mg} / \mathrm{L})$ & 0.05 & 0.03 & 0.07 & 0.06 & 0.07 & 0.07 & 0.12 & 0.07 & 0.17 & 0.1 \\
\hline Chl-a $(\mu g / L)$ & 18.0 & 37.7 & 87.5 & 67.9 & 102.1 & 96.6 & 190.6 & 242.9 & 359.3 & - \\
\hline
\end{tabular}

\subsubsection{Nutrient pollution}

$\mathrm{N}-\mathrm{NH}_{4}{ }^{+}$concentrations fluctuate between 0.082 and 5.1 $\mathrm{mg} / \mathrm{L}$ and usually peak at $\mathrm{N7}$ sample locations. The parameters meet $\mathrm{A} 2$ standard $\left(\mathrm{C}_{\mathrm{NH} 4+} \pm \varepsilon \leq 0.2 \mathrm{mg} / \mathrm{L}\right)$ at $\mathrm{N} 1$ samples, reach $\mathrm{B} 2$ standard at $\mathrm{N} 2, \mathrm{~N} 3, \mathrm{~N} 4$ and $\mathrm{N} 8\left(\mathrm{C}_{\mathrm{NH} 4+} \pm\right.$ $\varepsilon \leq 1 \mathrm{mg} / \mathrm{L})$, but those of N5, N6, N7 and N9 exceed the limit set by $\mathrm{B} 2\left(\mathrm{t}>t_{0.05 ; 5}\right)$.

$\mathrm{N}-\mathrm{NO}_{2}{ }^{-}$concentrations range from 0.01 to $0.35 \mathrm{mg} / \mathrm{L}$.

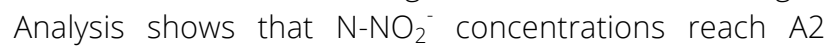
standard ( $\left.\mathrm{C}_{\mathrm{NO} 2} \pm \varepsilon \leq 0.02 \mathrm{mg} / \mathrm{L}\right)$ at $\mathrm{N} 1$, reach $\mathrm{B} 1$ standard at $\mathrm{N} 4$ and $\mathrm{N} 6\left(\mathrm{C}_{\mathrm{NO2}-} \pm \varepsilon \leq 0.04 \mathrm{mg} / \mathrm{L}\right)$. While the $\mathrm{N}-\mathrm{NO}_{2}$ concentrations at N2, N5, N7 and N8 are at B2 levels $\left(C_{\text {NO2- }} \pm \varepsilon \leq 0.05 \mathrm{mg} / \mathrm{L}\right)$, those at $\mathrm{N} 3$ and $\mathrm{N} 9$ are higher than B2 allowance $\left(\mathrm{t}>t_{0.05 ; 5}\right)$.

QCVN 08-MT:2015/BTNMT does not specify the limit set for total nitrogen (TN) and total phosphorus (TP). Therefore, this study referred to Danish standards, in which eutrophication threshold for TN and TP are respectively $0.1 \mathrm{mg} / \mathrm{L}$ and $0.15 \mathrm{mg} / \mathrm{L}$, as mentioned by Bui (2007). TN values of the studied locations exceed the limit given ( $\mathrm{t}>$ $\left.t_{0.05 ; 5}\right)$, ranging from $1.82 \mathrm{mg} / \mathrm{L}$ to $17.6 \mathrm{mg} / \mathrm{L}$; however, TP concentrations of most positions are below $0.15 \mathrm{mg} / \mathrm{L}$, except for $\mathrm{N} 7$ and $\mathrm{N9}$ ( $\mathrm{t}>t_{0.05 ; 5}$ ). This proves that the lakes are at risk falling into eutrophic state, mainly due to the large amount of accumulated nitrogen.

\subsubsection{Organic pollution}

$\mathrm{COD}$ and $\mathrm{BOD}_{5}$ concentrations of these ponds are fairly high; COD values are in the range of 91 to $572.903 \mathrm{mg} / \mathrm{L}$. All exceed the provision of B2 standard for COD (COD $\pm \varepsilon$ $\geq 50 \mathrm{mg} / \mathrm{L})\left(\mathrm{t}>4>t_{0.05 ; 5}\right)$. The values of $\mathrm{BOD}_{5}$ concentrations are also higher than $\mathrm{B} 2$ limit for $\mathrm{BOD}_{5}\left(\mathrm{BOD}_{5} \pm \varepsilon \geq\right.$ $25 \mathrm{mg} / \mathrm{L})$.

QCVN 08-MT:2015/BTNMT provides no criteria targeting chlorophyll-a, so the limit in this study is based on a research result of Lampert and Sommer (1993), cited in the study of Peerapornpisal, 1996, in order to predict phytoplankton's growth level in lakes and ponds, inferring nutritional status of the water bodies. Samples at N1 to N9 positions are all in the eutrophication conditions, since the average Chl-a concentrations are in the range of 10$100 \mathrm{~g} / \mathrm{L}$. Three locations N7, N8 and N9 are hypereutrophic (Chl-a $\pm \varepsilon>100 \mathrm{~g} / \mathrm{L}$ ), in which Chl-a value at N9 reaches $359.35 \pm \varepsilon \mu \mathrm{g} / \mathrm{L}$.

In general, the samples at N9 are the most polluted, due to the fact that many of their parameters are the highest value among the lakes, the most notable ones are the concentrations of Chl-a, representing a strong growth of phytoplankton species; N8 is contaminated the heaviest by organic matters, with COD value reaches $342.43 \pm 158$ $\mathrm{mg} / \mathrm{L}$. Meanwhile, N1 is the least polluted; however, its water quality is still being considered eutrophication since Chl-a values exceed 10 .

\subsection{Eutrophication assessment}

\subsubsection{Trophic state index TSI}

Analysis results in Figure 2 a show that 12/54 samples, accounted for $22.22 \%$, are in the state of eutrophication, and the remaining samples, accounted for $77.78 \%$, are in hyper-eutrophication conditions. Accreditation suggests that N9, whose TSI value is $87.68 \pm 3.84$ on average; $t_{0.05 ; 5}=11.27 ; p<0.05$ ) has the highest level of hypereutrophication. The locations from N2 to N8 have the average TSI value greater than 70 or approximately 70 , while N1 position is only at the level of eutrophication 
with an average TSI value of $64.47 \pm 3.01 ; t_{0.05 ; 5}=-4.51 ; \mathrm{p}$ $<0.05)$.

\subsubsection{Limiting factor}

Figure $2 b$ shows that the ratio of TN to TP is the lowest at N8 in the second sampling round, reaching 5.54, and the highest at N7 in the first sampling round, reaching 134.91. The TN/TP ratios of 40/54 samples (74.07\%) exceed 16 . The average TN/TP values of all samples are greater than or of the confidence interval of 16. Therefore, phosphorus is considered the limiting factor of eutrophication of these sample locations. This result agrees with the conclusion in the research of Nguyen et al. (2012) that phosphorus is the limiting factor in dry season.

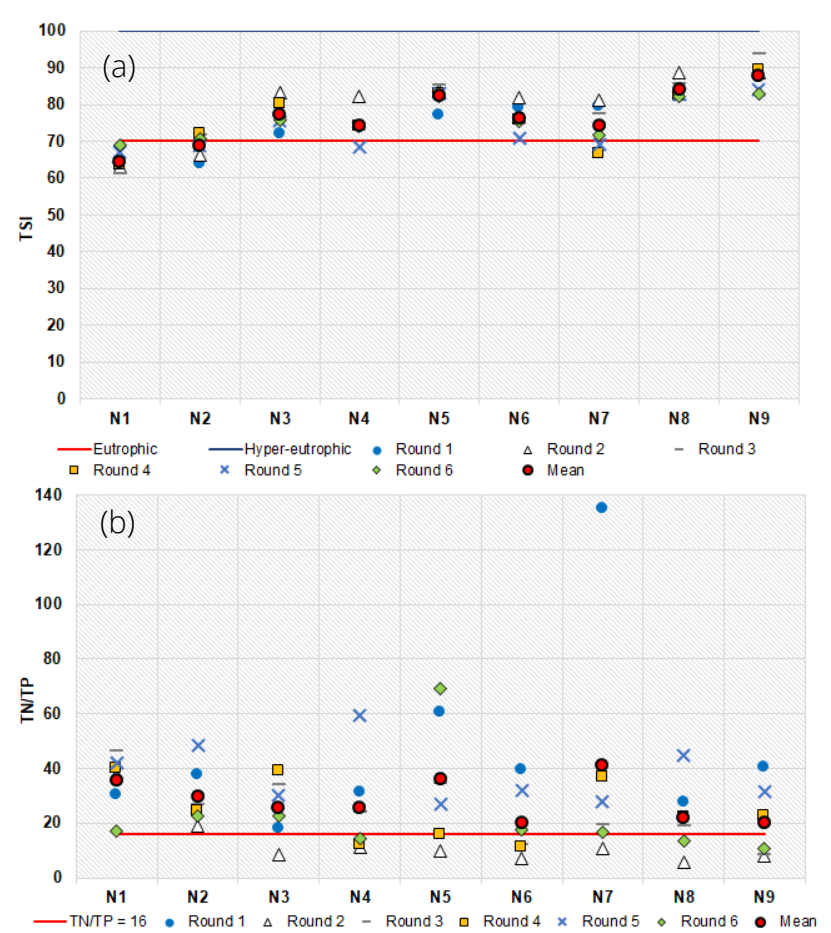

Figure 2. TSI (a) and TN/TP (b) results of the surveyed locations

\section{Conclusion}

After the survey in nine aquaculture ponds in Ho Chi Minh City, it is concluded that all of the researched ponds are under organic pollution (91 - $572.903 \mathrm{mg} / \mathrm{L}$ for COD and $43-263 \mathrm{mg} / \mathrm{L}_{\text {for }} \mathrm{BOD}_{5}$ ) and nutrient pollution (mainly $\mathrm{N}-\mathrm{NH}_{4}{ }^{+}$, from 0.082 to $5.1 \mathrm{mg} / \mathrm{L}$, and ${\mathrm{N}-\mathrm{NO}_{2}}^{-}$from 0.01 to $0.35 \mathrm{mg} / \mathrm{L}$, with the proportion of samples exceeding the standard B2 are 36/54 samples and 31/54 samples, respectively). Eight of the nine lakes are in a state of hypereutrophication (TSI average values are approximately 70 or greater than 70), while the remaining lake is in eutrophic conditions (TSI average value greater than 50). The eutrophication of water bodies can quickly increase the growth rate of algae (including toxic cyanobacteria) and contaminate of water sources and aquatic organisms, resulting in threatening consumers' health. As a result, it is urgent to propose measures, which can be based on the ratio of TN/TP, to handle and overcome the current situation and to monitor the water quality regularly to ensure public health.

\section{References}

[1] Bell-McKinnon, M. 2008. Liberty Lake Dataset Evaluation. Department of Ecology, Environmental Assessment Program, Washington, USA.

[2] Bui D.T., 2007. Some comments on the eutrophic status in Tri An, Dau Tieng, Thac Mo reservoirs. Proceedings of the 10th Scientific Conference - Vietnam Institute of Meteorology, Hydrology and Environment, Hanoi, 507-512 [in Vietnamese].

[3] Carlson R.E., 1977. A Trophic State Index for Lakes. Limnology and Oceanography, 22(2):361-369.

[4] EEA, 2005. European Environment Agency: core set of indicators. Guide, Technical Report No.1/2005.

[5] Fuller, L.M., and Jodoin, R.S, 2016. Estimation of a Trophic State Index for selected inland lakes in Michigan, 1999-2013: U.S. Geological Survey Scientific Investigations Report 2016-5023. Virginia, USA.

[6] Hansen, E., Christ, M., 2003. Suggested next steps to develop nutrient criteria for lakes and Reservoirs in West Virginia. WV Nutrient Criteria Committee, 2003 Next Steps for Lakes Criteria [retrieved from http://www.cacaponinstitute.org/lake_criteria.htm].

[7] HELCOM, 2009. Eutrophication in the Baltic Sea - An integrated thematic assessment of the effects of nutrient enrichment and eutrophication in the Baltic Sea region. Baltic Sea Environment Proceedings No. $115 \mathrm{~B}$.

[8] HEPA - Ho Chi Minh City Department of Natural Resources and Environment, 2016. A summary of the current state of environmental quality in $\mathrm{Ho}$ Chi Minh City in 2015. Ho Chi Minh City [in Vietnamese].

[9] Ho Chi Minh City Department of Agriculture and Rural Development, 2008. 2007 results and direction of fisheries in Ho Chi Minh City, Ho Chi Minh City.

[10] Ignatiades L., 2005. Scaling the trophic status of the Aegean Sea, eastern Mediterranean. Journal of Sea Research, 54:51-57.

[11] Jun Yang, Xiaoqing Yu, Lemian Liu, Wenjing Zhang, Peiyong Guo, 2012. Algae community and trophic state of subtropical reservoirs in southeast Fujian, China. Environmental Science and Pollution Research, 19(5):1432-1442.

[12] Lampert W., Sommer U., 1993. Limnoökologie. Georg Thieme Verlag, Stuttgart, ISBN 3137864011.

[13] Nguyen T.L.C., Hoang K.H., Truong V.H., 2015. Proposed measures to prevent algal blooming in Xuan Huong Lake, Da Lat city. Journal of Science \& Application, 21:72-75 [in Vietnamese]. 
[14] Nguyen, T.H. Nguyen, T.T.H., 2010. Study on the water quality of Dai Lai Lake in Vinh Phuc province through one year of measurement and data collection. Journal of Hydraulic and Environmental Engineering, 31, 57-64 [in Vietnamese].

[15] Nguyen, V.H., Pham, N.A.T., Nguyen, H.H., Vo, T.B.V., Thuy, C.T., 2012. Water quality and eutrophication status of lakes in Hue Citadel. Hue University Journal of Science, 73(4), 93-102 [in Vietnamese].

[16] Peerapornpisal, Y, 1996. Phytoplankton seasonality and limnology of three reservoirs in the Huai Hong Khrai Royal Development Study Centre, Chaing Mai, Thailand. Dissertation of the Ph.D. degree, Institute of Botanic, University of Innsbruck.

[17] Rui Ye, Kun Shan, Hailong Gao, Ruibin Zhang, Wen Xiong, Yulei Wang and Xin Qian, 2014. SpatioTemporal Distribution Patterns in Environmental Factors, Chlorophyll-a and Microcystins in a Large Shallow Lake, Lake Taihu, China. International Journal of Environmental Research and Public Health,
11:5155-5169.

[18] SPSS Inc. Released 2007. SPSS for Windows, Version 16.0. Chicago, SPSS Inc.

[19] VEA - Vietnam Environment Administration, 1995. Tiêu chuẩn Việt Nam TCVN 5994:1995 (ISO 56674:1987) - Water quality Sampling - Part 4: Guidance on sampling from natural lakes and man-made lakes. Hanoi [in Vietnamese].

[20] VEA - Vietnam Environment Administration, 2013. National Environment Report 2012: Surface water environment. Hanoi [in Vietnamese].

[21] VEA - Vietnam Environment Administration, 2015. National technical regulation QCVN 08-MT:2015 National technical regulation on surface water quality. Hanoi [in Vietnamese].

[22] Yang Xiao-e, Wu Xiang, Hao Hu-lin, He Zhen-li, 2008. Mechanisms and assessment of water eutrophication. Journal of Zheijang University SCIENCE B, 9(3):197-209. 